\title{
Effects of prescribed fire on Chamaespartium tridentatum ((L.)P. Gibbs) in Pinus pinaster (Aiton) forests
}

\author{
FRANCISCO C. REGO, STEPHEN C. BUNTING, AND M.G. BARREIRA
}

\section{Abstract}

Prescribed burning in Pinus pinaster forests was evaluated in terms of the effects on Chamaespartium tridentatum. Postfire forage quantity and quality were studied. Total biomass production, current year's shoot production, and nutritive value were studied in relation to time since fire. Chamaespartium, a vigorous resprouter, achieved $50 \%$ of its preburn biomass level in 2 years. Current year's shoot production reached a maximum 3 to 4 years after fire. Nutritive value of Chamcespartium was briefly enhanced by burning but returned to preburn levels. Seasonal variations of forage quality were very important with lower values in summer or fall. Short-lived increases in protein, cellulose, and hemi-cellulose contents after fire in Chamaespartium shoots returned to preburn levels in 4 years. This supported the traditional fire frequency in the shrublands of 3 to 7 in order to maintain forage quality and productivity. Key Words: biomass production, forage production, nutrition,
Portugal

The practice of prescribed burning was a traditional land management practice on Portuguese shrublands as in the whole Mediterranean Basin for over 3,000 years (Le Houerou 1973, Naveh 1974). However, during the current century the practice has become less common. Reforestation of shrublands with Pinus pinaster (Aiton) has resulted in decreased use of fire in order to protect the young plantations. Prescribed burning has been reintroduced into older pine forests recently as an experimental practice to evaluate the effects on wildfire control. Since these forests are also important forage producing areas, the effects of fire on production, nutritive value, and biomass accumulation of the understory vegetation was considered important to evaluate. Shrubs produce over $80 \%$ of the annual biomass on these sites with Chamaespartium tridentatum ((L.) P. Gibbs) present as the dominant shrub on many areas.

Aboveground biomass (referred to as biomass in this paper) of shrubs accumulates after fire at a rate depending upon the amount of sprouting species present at the time of the fire (Morgan and Neuenschwander 1988), the age of the burned stand, the conditions during and after fire, and various habitat factors. However, where regeneration is largely vegetative and is rapid and uniform, there are 3 main growth phases: (1) the building phase, corresponding with a continuing, approximately linear, increase of biomass; (2) the mature phase, in which total biomass accumulation begins to decline; and (3) the degenerate phase, represented by a levelling out and possibly decrease in total biomass (Gimingham 1972).

Estimates of total production in perennial, evergreen, woody vegetation are not easily obtained. Aboveground production consists of current year's shoot production and input to stem diameter. Several grazing studies have concentrated on the production of current year's shoots since these provide an index of the production of edible material (browse) and often comprise most of the biomass

\footnotetext{
Authors are auxiliary professor of range sciences, Departmento Florestal, Universidade de Tras-os-Montes e Alto Douro, Vila Real 5000 , Portugal; associate professor of range resources, University of Idaho, Moscow 83843, USA; and forest engineer, Direccao Geral dos Servicos Florestais, Braganca 5300, Portugal. Research was partly funded by the US Agency for International Development and the Direccao Geral dos Servicos Florestais. University of Idaho, Forest, Wild life and Range Experiment Station Contribution No. 382.

Manuscript accepted 10 May 1988.
}

removed by browsing, as shown for Calluna vulgaris ((L.) Hull) (Gimingham 1972, Milne 1974).

For Calluna vulgaris, Miller and Watson (1974) suggested a peak of shoot production in the building phase followed by progressive decline. Other studies in a variety of vegetation types have also documented increased annual shrub production for 3 to 5 years followed by declines in productivity (Lay 1965, Dills 1970). The ratio of annual shoot production to total above-ground biomass declines rapidly following a fire. Robertson and Davies (1965) showed that the proportion of young Calluna vulgaris shoots (the current and previous year's growth) drops from about $81 \%$ during the second year to about 21 and $14 \%$ by 15 and 35 years following a fire, respectively.

Published results on nutritional quality of postfire shrub forage are quite variable but, generally, indicate increases in nutrient content of shrubs are short lived. Increased nutrient level may last from only 1 year to as long as 20 years (Bendell 1974, Lyon et al. 1978). Miller and Watson (1974) found increase in nitrogen, phosphorus, magnesium, and potassium in Calluna vulgaris shoots after fire. Calcium initially decreases but then increases in concentration with a peak 5 years after fire. In spite of the reported variability most investigations agree that changes in nutrient concentrations occur within 5 years. Since increases in nitrogen and phosphorus are particularly significant for animal nutrition, burning will often improve quality of post-fire forage. Comparable twig segments obtained from recently burned sites are significantly more digestible than those from unburned sites. This is primarily due to increases in lignin and other cell wall components (Short et al. 1972). However, Milne (1974) found no significant differences in the digestibility of Calluna vulgaris twigs in stands of different ages.

\section{Methods}

This study was conducted in the mountain ranges separating Minho and Tras-os-Montes provinces in northern Portugal. Natural climax vegetation prior to human influence would have been dominated by deciduous oaks such as Quercus robur $\mathrm{L}$. and $Q$. pyrennaica Willd. (Braun-Blanquet et al. 1956). However, most original natural forest vegetation has been removed through wood cutting and wildfires. The vegetation of the region is now dominated by shrublands or forest plantations of Pinus pinaster. Sites were selected among mature stands of $P$. pinaster with dominant Chamaespartium tridentatum in the understory. Other common shrubs include: Calluna vulgaris, Erica arborea (L.), E. cinerea (L.) E. unbellata (L.) and Ulex minor (Roth). Grasses were a minor component of the community but Agrostis curtisii (Kerguelen) and Pseudarrhenatherum longifolium (Rouy) were commonly present on the sites. The age of the $P$. pinaster stands varied from 26 to 62 years old and tree dbh varied from 20 to $31 \mathrm{~cm}$. Total annual precipitation and mean annual temperature are approximately $1,000 \mathrm{~mm}$ and $13^{\circ} \mathrm{C}$ respectively, but show a close relation with elevation that varied from 280 to $880 \mathrm{~m}$. Soils are shallow and stony, and derived from schists and granites. Slope varied from 12 to $20 \%$. Areas subject to intensive grazing or other disturbances were avoided.

Five study sites were selected for prescribed burning at the beginning of the study. Each site was divided into 3 plots which are 
Table 1. Date of fire and fre characteriatics of preseribed fires conducted in Pinus pinaster forests in northern Portuzal. Windspeed for all prescribed fires was leas than $3 \mathrm{~km} / \mathrm{hr}$.

\begin{tabular}{llccc}
\hline \hline Fire location & Fire date & $\begin{array}{c}\text { Air } \\
\text { temp. } \\
\text { (C) }\end{array}$ & $\begin{array}{c}\text { Rel. } \\
\text { humidity } \\
(\%)\end{array}$ & $\begin{array}{c}\text { Flame } \\
\text { height } \\
(\mathrm{m})\end{array}$ \\
\hline Pedras Salgadas & Dec. 3, 1982 & 5.8 & 71 & 31.0 \\
& June 4, 1983 & 14.0 & 76 & 5.0 \\
Vieira do Minho & Dec. 28, 1982 & 11.1 & 67 & 6.0 \\
& May 24, 1983 & 18.5 & 69 & 1.0 \\
Amarante 1 & Nov. 22, 1982 & 14.0 & 72 & 1.5 \\
& Apr. 14, 1983 & 17.0 & 25 & 2.0 \\
Amarante 2 & Nov. 30, 1982 & 10.5 & 57 & 0.8 \\
& May 5, 1983 & 13.0 & 80 & 1.5 \\
Marao & Apr. 18, 1983 & 14.0 & 60 & 2.0 \\
\hline
\end{tabular}

0.25 to 0.5 ha in size. Two of each of these plots were prescribed burned with backfires between November 1982 and May 1983 (Table 1). On each of the 5 sites, 1 plot was burned in spring 1983. However, only 4 sites had burns in winter of 1982 . Vegetation data were collected prior to the fire. Data were collected for 4 consecutive years following the fires. In order to have as long-term information as possible on the ecological effects of burning, data were collected on sites that were prescribed burned prior to study initiation. These additional data were collected on 3 sites burned in 1979 and 2 sites burned in spring 1982.

Biomass determinations were made indirectly through previously developed relationships between biomass dry-weight for Chamaespartium tridentatum with cover and height. These relationships were established in $2 \times 5 \mathrm{~m}$ plots, where shrubs were measured for height and cover and then clipped and weighed. Cover was determined by the line intercept method (Canfield 1941) by placing 2 lines through the diagonals of the plot. Cover and height were measured to the nearest $\mathrm{cm}$. Dry weight biomass was determined by oven drying a subsample of the clipped sample at $65^{\circ} \mathrm{C}$ for 48 hours. A variety of Pinus pinaster-Chamaespartium tridentatum communities were sampled to develop an equation to predict Chamaespartium biomass values. These communities included the variation included in soils, slope, and elevation of the burned sites. These data resulted in the following regression equation:

$$
\mathrm{Y}=154.40 \times-1.850 \mathrm{X}^{2}, \quad R^{2}=0.877 \quad \mathrm{n}=22
$$

where $Y$ is the dry weight biomass $(\mathrm{Kg} / \mathrm{ha})$ and $X$ is the product of percent cover and height (m) for Chamaespartium.

Browse can be defined as the sum total of the plant material on woody species that is potentially edible to a specified set of animals. But commonly browse is viewed as current annual growth of leaves and twigs. In Calluna vulgaris, for example, the current annual growth generally comprises the bulk of the biomass utilized by herbivores (Gimingham 1972). Browse production can be estimated by determining the average weight per stem and estimating the average stems per plant (Wetzel et al. 1975). However, the always difficult task of defining the individual (plant or stem) becomes more difficult when working with species that propagate vegetatively (Mueller-Dombois and Ellenberg 1974) as Chamaespartium tridentatum. Therefore, we selected a procedure where the current year's shoots were hand-separated, and the proportion in whole shoots cut at ground level was computed. Since variability in this proportion is known to be low in even-aged stands $(10-20 \%$ of the mean, Gimingham and Miller 1968) this proportion was determined in small subsamples, and the weight of the current year's growth per unit area calculated from the total biomass of the samples (Gimingham 1972).

For determinations of forage quality, current year's shoots of
Chamaespartium tridentatum were collected during the 4 seasons in 1983, the first growing season following the fire. Three samples were collected at each prescribed burn site.

The dried forage was analyzed sequentially for the various cell wall components (CWC) as proposed by Goering and Van Soest (1970). Neutral-detergent fiber (NDF), acid-detergent fiber (ADF), and acid-detergent lignin (ADL) were measured. Cellulose was calculated by comparison of ADF and ADL, and hemi-cellulose by difference between NDF and ADF (Dietz 1972). Crude protein (Kjeldahl 6.25xN), ash, and dry matter of forage samples were determined by procedures described by A.O.A.C. (1975). In vitro organic matter digestibility (IVOMD) followed the method of Martens and Barnes (1980).

Biomass estimates were analyzed as a general linear model. Included in the model were sites and years after fire. Adjusted means (least square means) were used to build the model of biomass accumulation after fire.

Differences in forage chemical constituents were analyzed by an ANOVA using years after fire and season as sources of variation. Differences among means were determined with Duncan's multiple range test $(P=0.05)$, except when means of burned treatments were compared with the control. In that case the least significant difference $(P=0.05)$ was used (Steel and Torrie 1980).

\section{Results and Discussion}

Chamaespartium is a vigorous sprouter and well adapted to fire. Although biomass was reduced to nearly 0 during the fire, significant regrowth occurred every year during the first 4 years $(P<0.05)$. However, no significant differences were observed between the fall versus the spring burned plots. This is possibly a result of its adaptation to frequent fires and defoliation which have been prevalent in the Iberian Penninsula for a millenia (Le Houerou 1973). Variation in regrowth between sites was significant. Using the means, adjusted for differences between sites, a model was built relating Chamaespartium biomass $(\mathrm{Kg} / \mathrm{ha})$ to age after fire:

$$
\text { Chamaespartium biomass }=5800-4885 \mathrm{t}^{-0.6128} \quad \mathrm{R}^{2}=0.977 \quad \mathrm{n}=7
$$

Where $t$ equals years after fire.

The Chamaespartium current year's shoot biomass as a percentage of total biomass was related to age after fire in the following regression equation:

Current year's shoot percentage $=\left(0.457 t^{-0.385}\right) 100 \quad R^{2}=0.762 \quad n=37$

Where $t>1$. Current year's shoots equal $100 \%$ total biomass during the first year.

The equation relating percentage of current year's shoots to total Chamaespartium biomass was established using individual plot data, since variation between sites was not significant. As occurred in most reviewed literature, Chamaespartium current year's shoots increased rapidly, nearly doubling every year for the first 3 to 4 years after fire. The annual productivity rapidly declines following this period. Annual production may exceed $1,000 \mathrm{~kg} / \mathrm{ha}$ for the second to fourth year. It is estimated that annual production may decline to less than $500 \mathrm{~kg} / \mathrm{ha}$ by 20 years after the fire. Nearly all production of Chamaespartium is from resprouting plants so postfire biomass production is highly dependent upon preburn density.

Increased forage quantity may not be meaningful unless the quality is sufficiently high to sustain herbivores. Forage quality varies seasonally, between locations, and with age since fire. Chamaespartium quality on burned plots differed significantly from unburned sites (Table 2). We concluded that cellulose and hemicellulose increased significantly 6 months after fire, but their levels were not significantly different from the preburn level 2 years after burning. There was a delay between responses of cellulose and protein. Protein values were significantly higher between 6 months and 2 years after burning. Samples taken 4 years after fire were not significantly different from unburned plants for any component 
Table 2. Effects of prescribed fire on the nutritive value of Chamaespartium tridemtatum twigs in Pinus pinaster forests of northern Portugal.

\begin{tabular}{lccccc}
\hline \hline & \multicolumn{5}{c}{ Treatment means } \\
\cline { 2 - 6 } Cell wall & & \multicolumn{4}{c}{ Times since fire } \\
\cline { 2 - 6 } component (\%) & bur- & 3 & 6 & 2 & 4 \\
\hline Cellulose & 19.17 & $23.64^{*}$ & $24.84^{*}$ & $19.76^{*}$ & 19.78 \\
Hemi-cellulose & 9.55 & 9.99 & $11.68^{*}$ & 8.48 & 8.90 \\
Lignin & 25.86 & 24.97 & 23.83 & 24.57 & 25.86 \\
Protein & 8.96 & 9.67 & $10.51^{*}$ & 10.60 & 9.30 \\
Total organic & 91.83 & 92.18 & 91.70 & 91.66 & 92.10 \\
$\quad$ matter & & & & & \\
Organic matter & 41.75 & 41.49 & 42.29 & 46.05 & 44.11 \\
$\quad$ digestibility & & & & & \\
(in vitro) & & & & & \\
\hline
\end{tabular}

Means followed by an asterisk are significantly different from unburned $(P<0.05)$ as determined by the least significant difference (LSD).

analyzed. While not significant, lignin values seem to vary in opposition to those of cellulose and hemi-cellulose. The increase in protein following fire is important since $9 \%$ is near the deficiency level for some ruminants (National Research Council 1975).

Chamaespartium is the most important forage species in the community with respect to both quantity and quality. Nutrient quality of current year's shoots varies directly with growth stage (Short et al. 1972). Cellulose and hemi-cellulose were lower during the winter than during the other seasons (Table 3). Protein content

Table 3. Seasonal variation in the nutritional value of Chamaespartium tridentatum twigs in Pinus pinaster forests of northern Portugal.

\begin{tabular}{lcccc}
\hline \hline & \multicolumn{4}{c}{ Treatment means } \\
\cline { 2 - 5 } Cell wall component (\%) & Spring & Summer & Fall & Winter \\
\hline Cellulose & $22.18 \mathrm{~b}$ & $22.15 \mathrm{~b}$ & $21.75 \mathrm{~b}$ & $18.73 \mathrm{a}$ \\
Hemi-cellulose & $11.10 \mathrm{~b}$ & $9.96 \mathrm{~b}$ & $10.34 \mathrm{~b}$ & $8.45 \mathrm{a}$ \\
Lignin & $20.98 \mathrm{a}$ & $26.29 \mathrm{~b}$ & $26.03 \mathrm{~b}$ & $25.99 \mathrm{~b}$ \\
Protein & $9.62 \mathrm{ab}$ & $9.33 \mathrm{ab}$ & $9.16 \mathrm{a}$ & $10.11 \mathrm{~b}$ \\
Total organic matter & $90.68 \mathrm{a}$ & $92.46 \mathrm{c}$ & $91.95 \mathrm{~b}$ & $92.01 \mathrm{~b}$ \\
Organic matter digestibility & $44.47 \mathrm{~b}$ & $41.80 \mathrm{ab}$ & $39.89 \mathrm{a}$ & $44.41 \mathrm{~b}$ \\
$\quad$ (in vitro) & & & & \\
\hline
\end{tabular}

Means followed by a similar letter within the same row are not significantly different at the 0.05 level of probability, as determined by the Duncan's new multiple range test.

was greatest during the winter and least during the fall. Protein content during the other seasons was intermediate. Forage digestibility appeared to more closely related to low lignin and high protein content than to cellulose and hemi-cellulose content.

\section{Conclusions}

Chamaespartium tridentatum is a dominant species in post-fire succession of the understory vegetation in the pine forests of the study area. A vigorous sprouter, it produced $50 \%$ of the preburn biomass in 2 years and it is estimated that biomass will return to preburn levels in 7 to 10 years after fire.

The effect of fire on the nutritional quality of Chamaespartium twigs is in agreement with what has been found in other studies (Grant and Milne 1973, Milne 1974). Short-lived increases in cellulose and hemi-cellulose (6 months) with a related decrease in lignin. An increase of $1.5 \%$ in the protein content from 6 months to 2 years, approaching the preburn level after 4 years. While not dramatic, this increase allows the protein content of the twigs to be adequate to supply the gestation requirements of ewes (National Research Council 1975). A similar trend is apparent for forage digestibility.

Fire increased production of Chamaespartium browse and bene- fited browse quality for at least 2 years after prescribed fire. Shepherds traditionally have used fire in these shrub communities at intervals of 3 to 7 years. The results of this study provide evidence of the rationality of this fire-free-interval when the primary objective is to provide the greatest amount of high quality forage. This information enables forest managers to use prescribed burning as a management tool in this region to enhance livestock grazing in Pinus pinaster forests.

\section{Literature Cited}

Association of Omeial Analytical Chemists. 1975. Official Methods of Analysis (12th ed.) AOAC. Washington, D.C.

Bendell, J.F. 1974. Effects of fire on birds and mammals. p. 73-158. In: Fire and Ecosystems. Koslowski, T.T., and C.E. Ahlgren, eds. Academic Press, New York.

Braun-Blanquet, J., A.R.P. Sllva, and A. Roseira. 1956. Resultats de deux excursions geobotaniques a travers le Portugal septentrional et moyen. II. Chenaies a feuilles caduques (Quercion occidental) et chenaies a feuilles persistantes (Quercion fagineae) au Portugal. Agron. Lusitana 18:167-235.

Canfield, R. 1941. Application of the line interception method in range vegetation. J. Forest. 39:388-394.

Dietz, D.R. 1972. Nutritive value of shrubs. p. 289-302. In: Wildland shrubs - their biology and utilization. Logan, Utah. July 1971. USDA Forest Serv. Intermountain Forest and Range Exp. Sta. Gen. Tech. Rep. INT-1.

Dills, G.G. 1970. Effects of prescribed burning on deer browse. J. Wildl. Manage. 34:540-545.

Gimingham, C.H. 1972. Ecology of heathlands. Chapman and Hall. London.

Gimingham, C.H., and G.R. Miller. 1968. Measurement of the primary production of dwarf shrub heaths. p. 43-51. In: Milner, Co., and R.E. Hughes (eds.) Methods for the measurement of primary production of grassland. I.B.P. Handbook No. 6. Oxford and Edinburg.

Goering, H.D., and P.J. Van Soest. 1970. Forest fiber analysis (apparatus, reagents, procedures and some applications). USDA-ARS Handbook No. 379.

Grant, S.A., and J.A. Milne. 1973. Factors affecting the role of heather (Callune vulgaris L. Hull) in grazing systems. p. 41-46. In: Colloquium Proc. No. 3. Potassium Institute, Ltd.

Lay, D.M. 1957. Browse quality and the effects of prescribed burning in southern pine forests. J. Forest. 55:342-347.

Le Houerou, H.N. 1973. Fire and vegetation in the Mediterranean Basin. In: Proc. Tall Timbers Fire Ecology Conf. 13:237-277.

Lyon, L.J., H.S. Crawford, E. Czuhai, R.L. Fredricksen, R.F. Harlow, L.J. Metz, and H.A. Pearson. 1978. Effects of fire on fauna-a-state-ofknowledge review. USDA Forest Serv. Gen. Tech. Rep. W0-6.

Marten, G.C., and R.F. Barnes. 1980. Prediction of energy digestibility of forages with in vitro rumen fermentation and fungal enzyme systems. In: Standardization of analytical methodology for feeds. IDRC. Ottawa.

Milne, J.A. 1974. The effects of season and age of stand on the nutritive value of heather (Calluna vulgaris L. Hull) to sheep. J. Agr. Sci. 83:281288. Cambridge.

Miller, G.R., and A. Watson. 1974. Some effects of fire on vertebrate herbivores in the Scottish highlands. In: Proc. Tall Timbers Fire Ecology Conf. 13:39-64.

Morgan, P., and L.F. Neuenschwander. 1988. Shrub response to high and low severity burns. West. J. Applied Forest. 3:5-9.

Mueller-Dombols, D., and H. Dllenbert. 1974. Aims and methods of vegetation ecology. John Wiley and Sons. New York.

National Research Council. 1975. Nutrient requirements of domestic animals. No. 5. Fifth ed. Nat. Acad. Sci.-Nat. Res. Counc. Washington, D.C.

Naveh, Z. 1974. The ecology of fire in Israel. In: Proc. Tall Timbers Fire Ecology Conf. 13:131-170.

Robertson, R.A., and G.E. Davies. 1965. Quantities of plant nutrients in heather ecosystems. J. Appl. Ecol. 2:221-219.

Short, H.L., R.M. Blair, and L. Burkart. 1972. Factors affecting nutritive values. p. 311-318. In: Wildland shrubs-their biology and utilization. Logan, Utah. July 1971 . USDA Forest Serv. Intmtn. Forest and Range Exp. Sta. Gen. Tech. Rep. INT-1.

Steel, R.G.D., and J.H. Torrie. 1980. Principles and procedures of statistics. A biometrical approach. McGraw-Hill Book Co., New York.

Wetzel, J.F., J.R. Wambaugh, and J.M. Peek. 1975. Appraisal of whitetailed deer winter habitat in northeastern Minnesota. J. Wildl. Manage. 39:59-66. 